\title{
Effect of Curcumin Supplement in Summer Diet on Blood Metabolites, Antioxidant Status, Immune Response, and Testicular Gene Expression in Hu Sheep
}

\author{
Zhiyang Jiang ${ }^{1,2}$, Yongjie Wan ${ }^{1}$, Peng $\mathrm{Li}^{3}{ }^{3}$, Yang Xue ${ }^{1}$, Wenwen Cui ${ }^{1}$, Qi Chen ${ }^{1}$, Jianqin Chen ${ }^{1}$, \\ Feng Wang ${ }^{1}$ and Dagan Mao ${ }^{1,2, *}$ \\ 1 College of Animal Science and Technology, Nanjing Agricultural University, Nanjing 210095, Jiangsu, China; \\ 2018805102@njau.edu.cn (Z.J.); wanyongjie@njau.edu.cn (Y.W.); 2018105018@njau.edu.cn (Y.X.); \\ cuiwenwen0602@163.com (W.C.); clinqda@gmail.com (Q.C.); 2018805105@njau.edu.cn (J.C.); \\ caeet@njau.edu.cn (F.W.) \\ 2 National Experimental Teaching Demonstration Center of Animal Science, Nanjing Agricultural University, \\ Nanjing 210095, Jiangsu, China \\ 3 Qidong Ruipeng Animal Husbandry Co., Ltd, Nantong 226227, Jiangsu, China; lipeng1411@163.com \\ * Correspondence: maodagan@njau.edu.cn
}

Received: 12 August 2019; Accepted: 19 September 2019; Published: 24 September 2019

Simple Summary: Heat stress can induce oxidative stress and has an adverse effect on the growth and reproductive performance in animals. Curcumin, a plant-derived substance, with the effect of scavenging oxidative free radicals, improving immune response and anti-apoptosis, has been widely used as a dietary supplement in the livestock industry. The present study aims to investigate the effect of a curcumin dietary supplement on the blood metabolites, antioxidant status, immune response, and testicular gene expression in Hu Sheep in summer. The results show that dietary curcumin supplementation ( 450 and $900 \mathrm{mg} /$ per sheep daily) can promote lipid metabolism, antioxidant capacity, and immune response as well as testicular development in Hu sheep, which provides evidence for the protective role of curcumin against heat stress in sheep.

Abstract: In summer, the high temperature affects animal growth and reproductive performance. Curcumin is a flavonoid with anti-oxidant and anti-inflammatory effects. To evaluate the effects of dietary curcumin supplement on the blood biochemical parameters and testicular gene expressions in Hu sheep in summer, a total of 144 male Hu sheep aged four months were randomly divided into three groups (Con, Cur1, and Cur2, $\mathrm{n}=48$ ). Sheep in Con, Cur1, and Cur2 groups were fed a basal diet supplement with 0, 450, and $900 \mathrm{mg}$ (per sheep) curcumin daily, respectively. Sheep were fed for 35 days, including a pre-feed for seven days. The results showed that the supplement with $450 \mathrm{mg}$ and $900 \mathrm{mg}$ curcumin increased serum free fatty acid (NEFA) and glutathione peroxidase (GPX), as well as IgA and IgM. The supplement with $450 \mathrm{mg}$ curcumin increased the IgG level, while the supplement with $900 \mathrm{mg}$ curcumin had a lower IgG level than the supplement with $450 \mathrm{mg}$ curcumin $(p<0.05)$. Dietary curcumin supplement increased testicular organ index, serum testosterone level, and testicular star mRNA expression $(p<0.05)$. Furthermore, dietary curcumin supplement linearly inhibited testicular apoptosis with increased testicular bcl-2 mRNA expression and decreased caspase-3 mRNA expression $(p<0.05)$. In conclusion, dietary curcumin supplement can promote lipid metabolism, antioxidant capacity, and immune response, as well as testicular development, in Hu sheep, which provides evidence of application of curcumin in sheep production.

Keywords: curcumin; Hu sheep; high temperature environment; blood biochemical parameters; testis; gene expression 


\section{Introduction}

In summer in southern China, heat stress induced by high ambient temperature and humidity usually harms the growth and reproductive performance of animals. For male animals, the main manifestations are poor appetite, decreased feed intake and daily gain, lower sexual desire, decreased semen volume and sperm motility [1,2]. Usually, there will be some changes in the metabolism to prevent animals from greater harm by high ambient temperature [3-5]. When animals suffer from heat stress, their immune capacity will also decrease [6-9]. Numerous studies showed that heat stress induced oxidative stress, as reviewed by Nisar [10], which can cause DNA damage, cell apoptosis, and inflammation [11-13]. Other studies showed that heat stress can cause metabolic, immune, and reproductive disorders through the sympathetic-adrenal medullary system and the hypothalamic-pituitary-adrenal axis [14-16].

Recently, plant-derived antioxidants such as tomato pomace, betaine, turmeric rhizome powder, and Artemisia annua L were widely used as feed additives to enhance body function and alleviate stress damage [17-20]. Curcumin or curcuminoid of turmeric, a plant-derived substance, with the effect of scavenging oxidative free radicals due to its phenolic structure [21], can be used as an antioxidant in a daily dietary supplement. Studies have shown that curcumin has various effects, such as anti-cancer, anti-inflammatory, and anti-cardiovascular disease [21-25]. Curcumin also has a protective effect on DNA damage repair, prevention of spermatogenic cell apoptosis, and development of testicular tissue [26]. In the livestock, curcumin has been used to improve the enzyme activity, performance, egg quality, and anti-oxidative state [27-29]. It has been reported that nursing lambs fed diets with curcumin can significantly improve daily weight gain, production performance, metabolism, and immune performance [30].

Hu sheep is a local sheep breed in China with high reproductive characters [31]. However, in summer, the high temperature affects its growth and fertility. Previous studies have found that dietary betaine may have beneficial effects on sheep exposed to heat, and chestnut tannins can improve the meat quality, welfare, and antioxidant status of heat-stressed lambs [32,33]. Therefore, in this study, the effects of curcumin on the blood biochemical indexes and the expression of reproductive related genes in testis were evaluated during summer in Hu sheep, which provides evidence for the protective role of curcumin against heat stress in Hu sheep.

\section{Materal and Methods}

The investigational procedures involving Hu sheep were directed in agreement with the guide for the care and use of domestic animals organized by the Institutional Animal Care and Use Committee of Nanjing Agricultural University, China.

\subsection{Animals and Chemicals}

One hundred and forty male Hu sheep aged four months with bodyweight about $25.82 \pm 0.34 \mathrm{~kg}$ were used in this study. Hu sheep were housed at temperature $\left(33.32 \pm 0.33^{\circ} \mathrm{C}\right)$ and humidity level $(70.56 \% \pm 1.26 \%)$. Curcumin with the purity of $98 \%$ was purchased from Zhengzhou Baisite Food Additive Co., Ltd (Zhengzhou, China).

\subsection{Experimental Design}

Hu sheep were randomly divided into three groups $(n=48)$, with three replicates in each group and 16 sheep per replicate. Sheep were fed basal diets supplemented with $0 \mathrm{mg}$ (Con), $450 \mathrm{mg}$ (Cur1), $900 \mathrm{mg}$ (Cur2) curcumin (per sheep), respectively. The curcumin is mixed with the concentrate, the concentrate is then fed first and after that, the roughage is fed. Basal diets were formulated in Table 1. After the test with pre-feed for one week and formal feed for four weeks, sheep were 
weighed. The blood samples were collected to make serum and plasma, and the testes were collected and weighed, and then pieces were stored at $-80^{\circ} \mathrm{C}$ for further gene expression analysis.

Table 1. Formula and nutritional composition of the basal diet (based on dried matter).

\begin{tabular}{cccc}
\hline Item & Content/\% & Item & Content \\
\hline Concentrate & & & \\
Corn & 51.22 & $\mathrm{DE}(\mathrm{MJ} / \mathrm{Kg})$ & 12.81 \\
Wheat bran & 17.41 & $\mathrm{CP}(\mathrm{g} / \mathrm{Kg})$ & 171.73 \\
Barley bran & 15.91 & $\mathrm{Ca} / \%$ & 0.85 \\
Sesame & 4.98 & $\mathrm{P} / \%$ & 0.66 \\
Premix & 6.46 & & \\
NaHCO $_{3}$ & 2.48 & & \\
Salt & 1.49 & & \\
NaSeO $_{3}$ & 0.05 & & \\
Total & 100 & & \\
Roughage & & & \\
Silage & 52.24 & $\mathrm{DE}(\mathrm{MJ} / \mathrm{Kg})$ & 3.79 \\
Hay & 29.85 & $\mathrm{CP}(\mathrm{g} / \mathrm{Kg})$ & 49 \\
Soybean milk residue & 17.91 & $\mathrm{Ca} / \%$ & 0.4 \\
Total & 100 & $\mathrm{P} / \%$ & 0.07
\end{tabular}

Note: Ingredients contained in each kilogram of premix: Vitamin A $80 \mathrm{KIU} / \mathrm{kg}$, vitamin $\mathrm{D}_{3} 20 \mathrm{KIU} / \mathrm{kg}$, vitamin E 200 $\mathrm{mg} / \mathrm{kg}$, Fe 640 mg/kg, Mn 640 mg/kg, Cu 120 mg/kg, Zn 640 mg/kg, Co 2.5 mg/kg, I 10.5mg/kg, Se 2.5mg/kg. DE, digestible energy; $\mathrm{CP}$, crude protein; $\mathrm{Ca}$, calcium; $\mathrm{P}$, phosphorus.

\subsubsection{Body and Testis Weight}

At the end of the experiment, four sheep were randomly selected from each replicate to measure their body weight $(n=12)$ and the testes were castrated to measure their weight $(n=4)$.

\subsubsection{Serum Biochemical Parameters}

The serum concentration of glucose (Glu), non-esterified acid (NEFA), triglyceride (TG), low-density lipoprotein (LDL), high-density lipoprotein (HDL), total cholesterol (TC) was determined using the corresponding kits (Nanjing Jiancheng Institute of Bioengineering Ltd., Nanjing, China).

\subsubsection{Serum Activity of SOD and GPX}

The activity of the serum superoxide dismutase (SOD) and glutathione peroxidase (GPX) was determined using the corresponding kits (Nanjing Jiancheng Institute of Bioengineering Ltd., Nanjing China).

\subsubsection{The Plasma Concentration of $\operatorname{IgA}$, IgM, and IgG}

The plasma concentration of immunoglobulin A (IgA), immunoglobulin $\mathrm{M}(\operatorname{IgM})$ and immunoglobulin $\mathrm{G}(\mathrm{IgG})$ was determined using enzyme-linked immunosorbent assay method (ELISA, Nanjing Jiancheng Institute of Bioengineering Ltd., Nanjing China), respectively.

\subsubsection{Quantitative Real-Time PCR}

The total RNA was extracted from frozen testes using Trizol Reagent (TaKaRa Biotechnology Co. Ltd., Dalian, China). The concentration and purity of RNA were determined with a spectrophotometer (NanoDrop 2,000c, Thermo Scientific, USA). For each sample, $5 \mu \mathrm{g}$ of total RNA was treated with DNase I (TaKaRa) to remove DNA, and then the cDNA was synthesized by reverse transcription on Veriti 9902 Thermal Cycler (Applied Biosystems, USA) using the PrimeScript RT Reagent kit (TaKaRa). The reactions were incubated for $15 \mathrm{~min}$ at $37^{\circ} \mathrm{C}$, followed by $5 \mathrm{~s}$ at $85^{\circ} \mathrm{C}$. Real-time PCR was performed using the QuantStudio ${ }^{\circledR} 5$ Real-Time PCR Design and Analysis System (Applied Biosystems, USA) with a SYBR@Premix Ex Taq ${ }^{\mathrm{TM}}$ Kit (TaKaRa Biotechnology Co. Ltd., Dalian, China). The reactions 
include TB Green Premix Ex Taq $(10 \mu \mathrm{L})$, PCR Primers $(0.8 \mu \mathrm{L})$, ROX Reference Dye II $(0.4 \mu \mathrm{L})$, DNA template $(2 \mu \mathrm{L})$ and sterilized water with a final volume of $20 \mu \mathrm{L}$, and the cycling conditions were as follows: $95^{\circ} \mathrm{C}$ for $30 \mathrm{~s}$ (Hold stage), followed by 40 cycles of $95^{\circ} \mathrm{C}$ for $5 \mathrm{~s}$ and $60^{\circ} \mathrm{C}$ for $30 \mathrm{~s}$ (PCR stage), then $95^{\circ} \mathrm{C}$ for $15 \mathrm{~s}, 60{ }^{\circ} \mathrm{C}$ for one min, and $95^{\circ} \mathrm{C}$ for $15 \mathrm{~s}$ (Melt curve stage). The primer sequence for the genes was obtained from the NCBI database (Table 2). The values of all genes' mRNA expression were normalized to $a c t b$ and were calculated using the $2^{-\Delta C T}$ method.

Table 2. Primers used for quantitative real-time PCR analysis of genes expressions.

\begin{tabular}{|c|c|c|c|}
\hline Gene & Primer Sequence $\left(5^{\prime}-3^{\prime}\right)$ & Product Size (bp) & GeneBank Accession Number \\
\hline star & $\begin{array}{c}\text { F: GGGCATCCTCAAAGACCAG } \\
\text { R: TCCACCACCACСТCСАAC }\end{array}$ & 120 & NM_001009243.1 \\
\hline$h s d 3 b$ & $\begin{array}{c}\text { F: ATCCACACCAGCACCATAG } \\
\text { R: TTCCAGCACAGCCTTCTC }\end{array}$ & 144 & NM_001135932.1 \\
\hline$b c l-2$ & $\begin{array}{c}\text { F: CGCATCGTGGCCTTCTTT } \\
\text { R: CGGTTCAGGTACTCGGTCATC }\end{array}$ & 113 & XM_027960877.1 \\
\hline caspase-3 & $\begin{array}{l}\text { F: TCAGGGAAACCTTCACGAGC } \\
\text { R: CCTCGGCAGGCCTGAATAAT }\end{array}$ & 274 & XM_027962551.1 \\
\hline$a c t b$ & $\begin{array}{l}\text { F: CCAAGGCCAACCGTGAGAAG } \\
\text { R: CCATCTCCTGCTTCGAAGTCC }\end{array}$ & 349 & NM_001009784.3 \\
\hline
\end{tabular}

Note: star, steroidogenic acute regulatory protein; hsd3b, 3ß-hydroxysteroid dehydrogenase; bcl-2, B-cell lymphoma-2; actb, $\beta$-Actin.

\subsubsection{Plasma Testosterone Concentration}

Plasma testosterone concentration was determined using ELISA kit (Nanjing Jiancheng Institute of Bioengineering Ltd., Nanjing China). The assay sensitivity was $0.02 \mathrm{ng} / \mathrm{mL}$. The intra-assay and inter-assay coefficients of variation were $<10 \%$ and $<15 \%$, respectively.

\subsubsection{Statistical Analysis}

All data are expressed as the mean \pm standard error of the mean (SEM), and differences in means were analyzed by one-way analysis of variance (ANOVA) followed by Tukey's multiple comparison test using SPSS version 22.0, and $p<0.05$ means significant difference.

\section{Result}

\subsection{Serum Biochemical Parameters}

Curcumin supplement increased the serum concentration of NEFA, which was significantly higher in Cur2 than those in other groups $(p<0.05)$. However, curcumin supplement did not change serum concentrations of Glu, TG, LDL, HDL, and TC (Table 3).

Table 3. Effect of curcumin supplement on serum biochemical indices in Hu sheep (means $\pm S E M, n=12$ ).

\begin{tabular}{cccc}
\hline Item & Con & Cur1 & Cur2 \\
\hline Glu (mmol/L) & $3.37+0.81$ & $3.30+0.89$ & $3.81+1.17$ \\
TC (mmol/L) & $3.00+0.43$ & $3.26+0.36$ & $3.30+0.52$ \\
TG (mmol/L) & $0.31+0.08$ & $0.33+0.06$ & $0.34+0.08$ \\
NEFA (mmol/L) & $0.26+0.07^{\mathrm{a}}$ & $0.30+0.08^{\mathrm{ab}}$ & $0.36+0.09 \mathrm{~b}$ \\
HDL (mmol/L) & $0.85+0.14$ & $0.88+0.11$ & $0.87+0.10$ \\
LDL (mmol/L) & $0.71+0.11$ & $0.73+0.15$ & $0.71+0.16$ \\
\hline
\end{tabular}

Note: ${ }^{a, b}$ Values with different superscript means significant difference $(p<0.05)$.Glu, glucose; TC, total cholesterol; TG, triglyceride; NEFA, non-esterified acid; HDL, high-density lipoprotein; LDL, low-density lipoprotein. 


\subsection{Serum SOD and GPX activity}

Curcumin supplement increased serum activity of GPX, which was significantly higher in Cur2 than that in Cur1 (Figure 1a, $p<0.05$ ). However, the activity of SOD was not significantly different in all groups (Figure $1 b, p>0.05$ ).

(a)

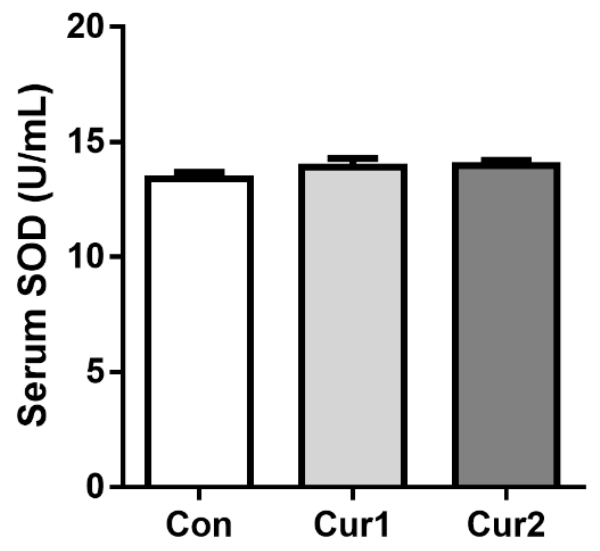

(b)

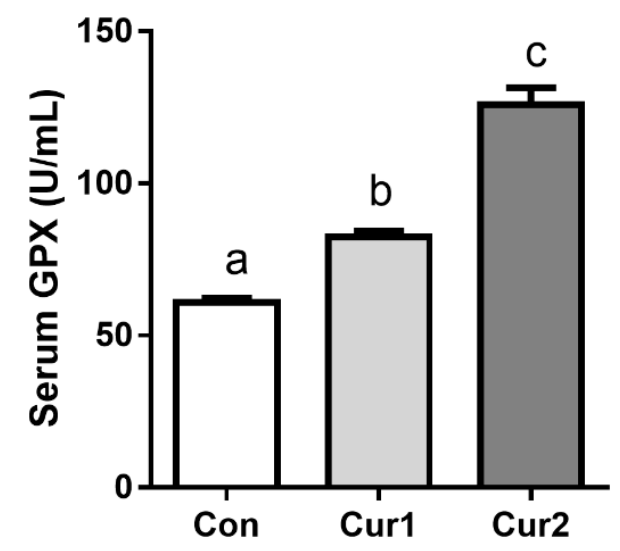

Figure 1. Effect of dietary curcumin supplement on the anti-oxidative capacity in Hu sheep in summer. Sheep in Con, Cur1, and Cur2 groups were fed basal diets supplemented with $0 \mathrm{mg}$, $450 \mathrm{mg}$, and $900 \mathrm{mg}$ curcumin (per sheep) daily for 35 days, respectively. Serum was then collected to measure SOD (a) and GPX activity $(b)$ by commercial kits. Data are shown as means \pm SEM $(n=12)$. Bars with different letters denote significant differences $(p<0.05)$. SOD, superoxide dismutase; GPX, glutathione peroxidase.

\subsection{Plasma Concentration of $\operatorname{IgA}$, IgM, and IgG}

Curcumin supplement increased the plasma level of $\operatorname{IgA}$ and IgM in a dose-dependent manner (Figure 2a,b, $p<0.05$ ). Curcumin supplement also increased the plasma level of IgG. However, the plasma concentration of IgG in Cur1 was higher than that in Cur2 (Figure 2c, $p<0.05$ ).

(a)

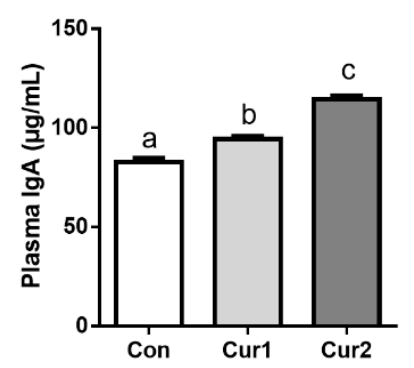

(b)

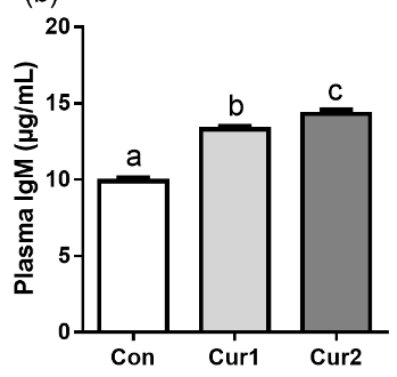

(c)

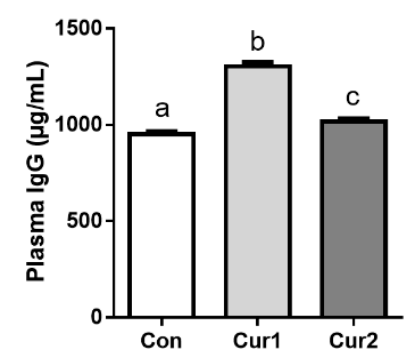

Figure 2. Effect of dietary curcumin supplement on the immune capacity in Hu sheep in summer. Sheep in Con, Cur1, and Cur2 groups were fed basal diets supplemented with $0 \mathrm{mg}, 450 \mathrm{mg}$, and $900 \mathrm{mg}$ curcumin (per sheep) daily for 35 days, respectively. Plasma was then collected to measure IgA (a), IgM (b) and $\operatorname{IgG}(\mathbf{c})$ concentration by ELISA. Data are shown as means \pm SEM $(n=12)$. Bars with different letters denote significant differences $(p<0.05)$. IgA, immunoglobulin A; IgM, immunoglobulin M; IgG, immunoglobulin G.

\subsection{Testis Weight/Body Weight, Testosterone Concentration and Androgen-Related Gene Expressions}

Curcumin supplement increased the relative testis weight (TW/BW) in Cur2 compared with those in Con and Cur1 (Figure 3a, $p<0.05$ ), while there was no significant difference in TW/BW between Con and Cur1 $(p>0.05)$. Similarly, testosterone in plasma also had significant differences in Con and Cur2 (Figure 3b). The testicular star mRNA level in Cur2 was significantly higher than those in Cur1 and 
Con (Figure $3 c, p<0.05$ ). However, there was no significant difference in the testicular hsd3b mRNA expression among all the groups (Figure $3 \mathrm{~d}, p>0.05$ ).

(a)

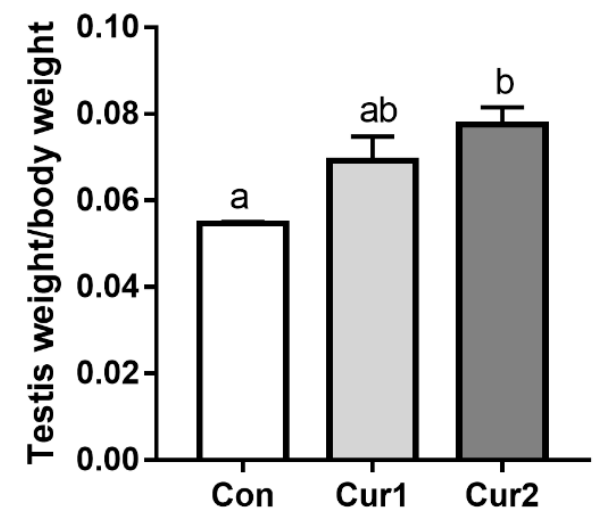

(c)

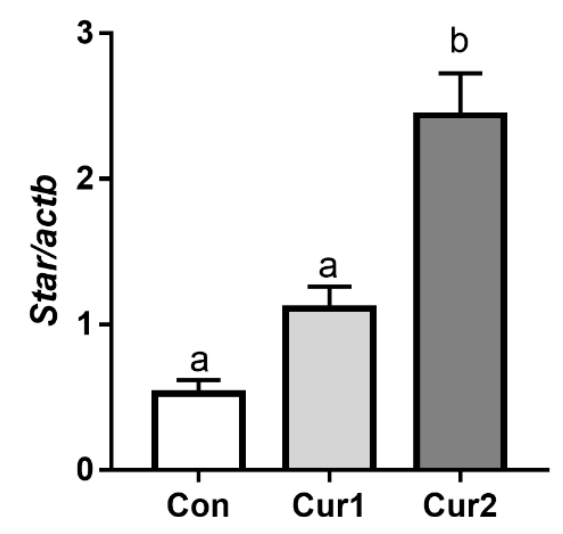

(b)

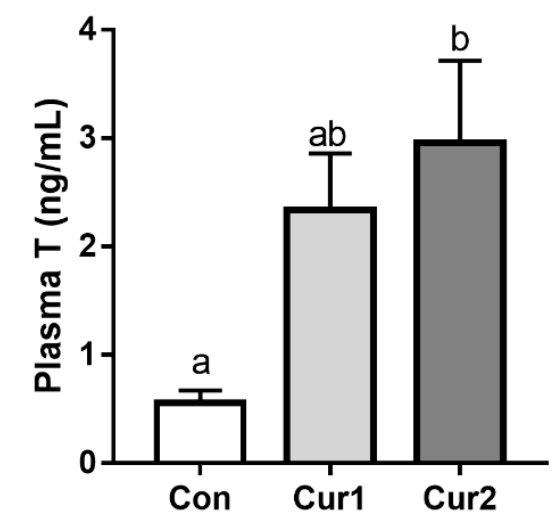

(d)

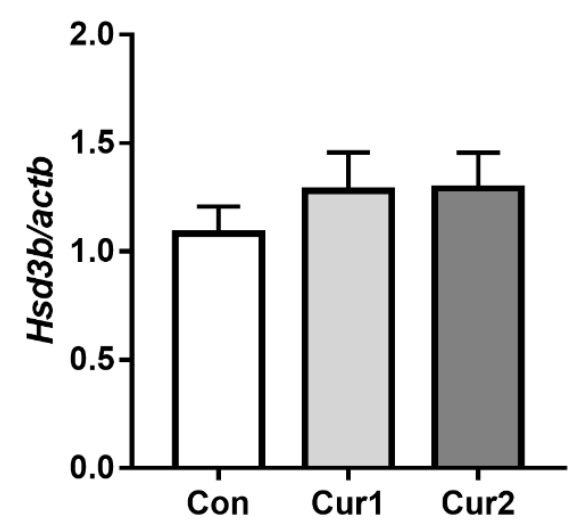

Figure 3. Effect of dietary curcumin supplement on testosterone concentration and testicular steroidogenic gene expressions in Hu sheep in summer. Sheep in Con, Cur1, and Cur2 groups were fed basal diets supplemented with $0 \mathrm{mg}, 450 \mathrm{mg}$, and $900 \mathrm{mg}$ curcumin (per sheep) daily for 35 days, respectively. Testes weight normalized to body weight (a). Plasma testosterone concentration (b) was detected by ELISA ( $n=12)$. Testicular star mRNA (c) and hsd3b mRNA (d) expressions were analyzed by quantitative real-time PCR $(n=4)$, the y-axis scale is folded relative to actb. Data are shown as means \pm SEM. Bars with different letters denote significant differences $(p<0.05)$. T, testosterone; star, steroidogenic acute regulatory protein; hsd $3 b, 3 \beta$-hydroxysteroid dehydrogenase; actb, $\beta$-Actin.

\subsection{Expression Patterns of Apoptosis-Related Genes in Testis}

Testicular bcl-2 mRNA expression in Cur2 increased compared with Con and Cur1 $(p<0.05)$. However, there was no significant difference between Con and Cur1 (Figure 4a, $p>0.05$ ). Conversely, the testicular expression level of caspase -3 gene in Cur2 decreased significantly compared with Con and Cur1 $(p<0.05)$, and there was no significant difference between Con and Cur1 (Figure $4 b, p>0.05$ ). 
(a)

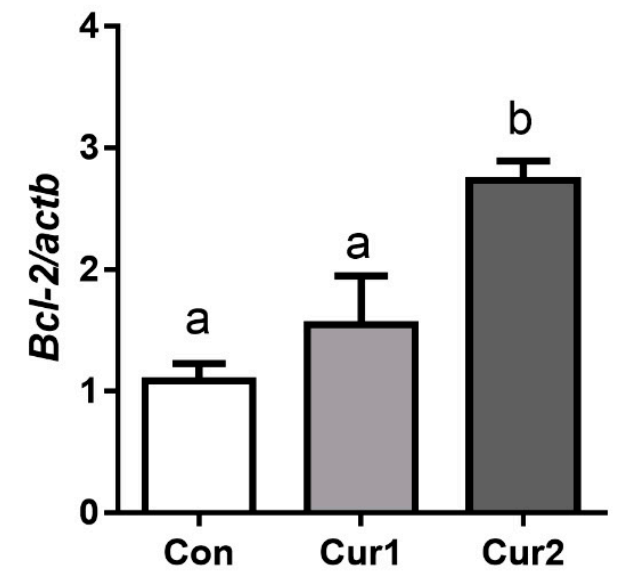

(b)

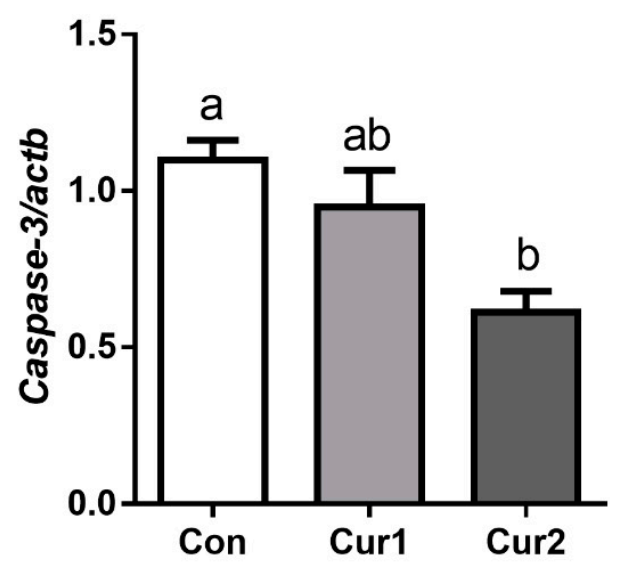

Figure 4. Effect of dietary curcumin supplement on testicular apoptotic gene expressions in Hu sheep in summer. Sheep in Con, Cur1, and Cur2 groups were fed basal diets supplemented with $0 \mathrm{mg}, 450 \mathrm{mg}$, and $900 \mathrm{mg}$ curcumin (per sheep) daily for 35 days, respectively. Testicular tissues were collected to detect anti-apoptotic bcl-2 (a) and apoptotic caspase-3 (b) mRNA expressions by quantitative real-time PCR. Data are shown as means \pm SEM $(n=4)$. Bars with different letters denote significant differences $(p<0.05)$. The y-axis scale is folded relative to actb. bcl-2, B-cell lymphoma-2; actb, $\beta$-Actin.

\section{Discussion}

A previous study in nursing lambs showed that diets supplemented with curcumin can improve the growth performance, metabolism, and immune response. The current study investigates the effect of summer dietary curcumin supplement on the blood metabolites and testicular development in Hu sheep.

The biochemical parameters in serum can reflect animal metabolic status. A previous study has reported that heat stress can affect metabolism, which decreased the serum concentration of NEFA but not Glu in growing pigs [4]. Exposure to high heat load did not affect the concentrations of Glu, TG or NEFA in Australian Merino sheep [34]. However, curcumin supplement increased hepatic NEFA concentration and decreased plasma LDL cholesterol and hepatic TG concentrations in broiler chickens [35]. Curcumin also decreased the concentrations of plasma TG, TC, LDL cholesterol, and increased plasma HDL cholesterol and caused transcriptional inhibition of HMG-CoA reductase in mice fed high cholesterol [36]. Numerous studies, as reviewed by Zingg, showed curcumin can lower blood lipid levels [37]. It is reported that grape seed extract decreased serum TC, TG, LDL, and VLDL concentration, and vitamin C supplement decreased serum TC concentration in broilers suffering from heat stress [38]. The current increase in serum concentration of NEFA indicates that dietary curcumin supplement can promote fat mobilization in $\mathrm{Hu}$ sheep. Plasma cholesterol is transported back to the liver for metabolism by HDL, while it is transported to tissues by LDL. It is generally believed that higher HDL and lower LDL are beneficial to the organism. However, dietary curcumin supplement in the current study had no effect on Glu, TC, TG, HDL, and LDL, which might be due to the animal species and the dosage of curcumin. A study showed that different dosages of curcumin have different effects on serum biochemistry of nursing lambs and curcumin exerted few effects on hematological parameters [39] in which only $200 \mathrm{mg} / \mathrm{kg}$ curcumin increased serum levels of glucose and urea on day 30 of experiment, while both $100 \mathrm{mg} / \mathrm{kg}$ and $200 \mathrm{mg} / \mathrm{kg}$ decreased serum levels of total protein and globulin and increased the cholesterol levels on days 15 and 30.

Heat stress usually induces ROS (reactive oxygen species), which can lead to oxidative stress [40]. SOD and GPX are antioxidant parameters that can scavenge ROS, and their activities are usually used to evaluate antioxidant ability in testis [41]. A previous study has reported that curcumin can up-regulate the relevant antioxidant enzymes through the Nrf-2 gene to alleviate the damage caused by heat stress, and increase the activity of SOD and GPX in mouse testis [42]. Studies have 
shown curcumin supplement can increase the serum SOD and GPX in poultry and sheep [43,44]. It is reported that low-dose curcumin-loaded Eudragit L-100-nanocapsules in the diet of dairy sheep increases antioxidant levels and reduces lipid peroxidation in milk [39]. Other studies showed the levels of MDA, and activities of lactate dehydrogenase and nitric oxide synthase were reduced, and the levels of T-AOC and GSH were enhanced when mouse fed the Mung bean flavonoids. while dietary resveratrol increased the activities of GSH-PX, SOD, CAT, and decreased the MDA level in serum of black-boned chickens and rats $[45,46]$. The current increase in GPX activity indicates that dietary curcumin supplement can improve the antioxidant capacity though it did not affect the serum activity of SOD in Hu sheep, and curcumin enhances antioxidant status by increasing GPX not SOD in Hu sheep.

Numerous studies, as reviewed by Aggarwal, have shown that heat stress decreased immune performance in animals [47]. Heat stress can change the body metabolic status accompanied by inflammation to weaken the immune function [48]. Studies have shown that heat stress can reduce the concentration of IgA, IgM, and IgG in poultry $[49,50]$. Other studies found that diets supplemented with tomato pomace, betaine, and turmeric rhizome powder increased the concentrations of total antibody, IgM, and IgG in the serum of broilers exposed to heat stress [17,19]. Dietary curcumin supplement can increase the serum concentration of IgG in lactating cows reared under high ambient temperature environment [51]. The current result of the increase in serum concentration of $\operatorname{IgA}$, IgG, and IgM after curcumin supplement in Hu sheep was consistent with the previous study that curcumin increased IgG and IgM levels in rats under 2,3,7,8 Tetrachlorodibenzo -p-dioxin (TCDD) exposure [52]. However, the decreased IgG level in a high dosage of curcumin group might be a potentially toxic effect of curcumin $[53,54]$ which needs further study.

Animals in high ambient temperature environment usually have poor testicular development compared with that in a normal environment. A previous study has shown that heat stress causes a reduction in testicular weight and desquamation of germ cells from seminiferous tubules, and the diameter of the seminiferous tubules becomes smaller, spermatogenic cells are shed, and the spermatogenic cells are arranged irregularly [55]. Trans-Resveratrol can increase sperm output, testosterone, and promote testicular development in healthy rats [56]. It is reported that curcumin dose-dependently improved spermatogenic disorders induced by scrotal heat stress in mice, and vitamin E promoted the development of reproductive organs in Boer goat [55,57]. Therefore, the current increase in relative testicular weight after dietary curcumin supplement might indicate that curcumin can stimulate testicular development in summer.

Testosterone is synthesized and secreted by interstitial Leydig cells in testes [58]. The Leydig cells synthesize steroid hormones from cholesterol which is the same as all other steroid-producing cells [59]. Testosterone synthesis is regulated by relative steroid-producing genes such as star and hsd3b [60]. Previous studies showed heat stress could decrease the star mRNA expression in mice testes [61] and dietary supplemented with curcumin can increase testicular hsd3b mRNA expression and the concentration of testosterone in heat stress in mice [62]. Studies also showed flavonols and quercetin derivative compounds increased star gene expression in MA-10 Leydig cells $[63,64]$. The current increase in serum testosterone concentration and testicular star mRNA expression might indicate that dietary curcumin supplement can improve the reproductive performance of Hu sheep.

In hot summer, the high temperature of the scrotum leads to testicular cell apoptosis, spermatogenic disorders, and male infertility $[65,66]$. Previous studies have shown that heat stress can reduce testicular bcl-2 mRNA expression in pigs [67], and increase caspase-3 gene expression in rats [42], and dietary lycium polysaccharide supplement increased testicular bcl-2 mRNA expression and decreased caspase-3 mRNA gene expression after heat stress in rats [68], which was consistent with the study of Lin C that curcumin has the effect on anti-apoptosis [55]. Curcumin can alleviate testicular damage, cell apoptosis, and spermatogenic cell death induced by streptozotocin and aflatoxin $[69,70]$. Therefore, the current increase in bcl- 2 and decrease in caspase- 3 gene expression indicate that dietary curcumin supplement can alleviate the testicular cell apoptosis in sheep production in summer. 


\section{Conclusions}

Dietary curcumin supplement with 450 and 900 mg (per sheep) can increase NEFA and GPX in serum, which indicates curcumin promotes lipid metabolism and improves antioxidant status in $\mathrm{Hu}$ sheep. Dietary curcumin supplement improves immune ability by increasing the concentrations of $\operatorname{IgA}$, IgM, and IgG in plasma. Results of the increase of testosterone in plasma, star, and hsd $3 \mathrm{~b}$ genes expression showed curcumin dose-dependently improves the reproductive performance of Hu sheep. The current increase in bcl-2 and decrease in caspase- 3 gene expression showe that curcumin can prevent testicular cell apoptosis.

Author Contributions: Z.J., D.M., Y.W., and F.W. designed, drafted and contributed with the experiment design and the paper corrections. P.L. provided experimental animals. Z.J., Y.X., W.C., Q.C., and J.C. carried out the experiment and analyzed data.

Acknowledgments: This work was supported by National Key R \& D Program of China (2018YFD0501906) and Jiangsu Key R \& D Program (Modern Agriculture) (BE2017320).

Conflicts of Interest: None of the authors have any conflict of interest to declare.

Date Availability Statement: The data that support the findings of this study are available from the corresponding author upon reasonable request.

\section{References}

1. Belhadj Slimen, I.; Najar, T.; Ghram, A.; Abdrrabba, M. Heat stress effects on livestock: Molecular, cellular and metabolic aspects, a review. J. Anim. Physiol. Anim. Nutr. 2016, 100, 401-412. [CrossRef] [PubMed]

2. Ross, J.W.; Hale, B.J.; Seibert, J.T.; Romoser, M.R.; Adur, M.K.; Keating, A.F.; Baumgard, L.H. Physiological mechanisms through which heat stress compromises reproduction in pigs. Mol. Reprod. Dev. 2017, 84, 934-945. [CrossRef] [PubMed]

3. Hall, D.; Xu, L.; Drake, V.; Oberley, L.; Oberley, T.; Moseley, P.; Kregel, K. Aging reduces adaptive capacity and stress protein expression in the liver after heat stress. J. Appl. Physiol. 2000, 89, 749-759. [CrossRef] [PubMed]

4. Victoria Sanz Fernandez, M.; Johnson, J.S.; Abuajamieh, M.; Stoakes, S.K.; Seibert, J.T.; Cox, L.; Kahl, S.; Elsasser, T.H.; Ross, J.W.; Clay Isom, S. Effects of heat stress on carbohydrate and lipid metabolism in growing pigs. Physiol. Rep. 2015, 3, e12315. [CrossRef] [PubMed]

5. Chen, S.; Wang, J.; Peng, D.; Li, G.; Chen, J.; Gu, X. Exposure to heat-stress environment affects the physiology, circulation levels of cytokines, and microbiome in dairy cows. Sci. Rep. 2018, 8, 14606. [CrossRef] [PubMed]

6. Hicks, T.A.; McGlone, J.J.; Whisnant, C.S.; Kattesh, H.G.; Norman, R.L. Behavioral, endocrine, immune, and performance measures for pigs exposed to acute stress. Sci. J. Anim. Sci. 1998, 76, 474-483. [CrossRef] [PubMed]

7. Mashaly, M.; Hendricks 3rd, G.; Kalama, M.; Gehad, A.; Abbas, A.; Patterson, P. Effect of heat stress on production parameters and immune responses of commercial laying hens. Poult. Sci. J. 2004, 83, 889-894. [CrossRef]

8. Tao, S.; Monteiro, A.; Thompson, I.; Hayen, M.; Dahl, G. Effect of late-gestation maternal heat stress on growth and immune function of dairy calves. J. Dairy Sci. 2012, 95, 7128-7136. [CrossRef]

9. Zulkifli, I.; Che Norma, M.; Israf, D.; Omar, A. The effect of early age feed restriction on subsequent response to high environmental temperatures in female broiler chickens. Poult. Sci. J. 2000, 79, 1401-1407. [CrossRef]

10. Nisar, A.; Sultana, M.; Ashraf, H. Oxidative stress-threat to animal health and production. Int. J. Livest. Res. 2013, 3, 76-83.

11. Cong, X.; Zhang, Q.; Li, H.; Jiang, Z.; Cao, R.; Gao, S.; Tian, W. Puerarin ameliorates heat stress-induced oxidative damage and apoptosis in bovine Sertoli cells by suppressing ROS production and upregulating Hsp72 expression. Theriogenology 2017, 88, 215-227. [CrossRef] [PubMed]

12. Kantidze, O.; Velichko, A.; Luzhin, A.; Razin, S. Heat stress-induced DNA damage. Acta Nat. 2016, 8. [CrossRef]

13. Quinteiro-Filho, W.M.; Gomes, A.; Pinheiro, M.L.; Ribeiro, A.; Ferraz-de-Paula, V.; Astolfi-Ferreira, C.S.; Ferreira, A.J.P.; Palermo-Neto, J. Heat stress impairs performance and induces intestinal inflammation in broiler chickens infected with Salmonella Enteritidis. Avian Pathol. 2012, 41, 421-427. [CrossRef] [PubMed] 
14. Caroprese, M.; Ciliberti, M.G.; Annicchiarico, G.; Albenzio, M.; Muscio, A.; Sevi, A. Hypothalamicpituitary-adrenal axis activation and immune regulation in heat-stressed sheep after supplementation with polyunsaturated fatty acids. J. Dairy Sci. 2014, 97, 4247-4258. [CrossRef] [PubMed]

15. Maurya, V.; Sejian, V.; Kumar, D.; Naqvi, S. Impact of heat stress, nutritional restriction and combined stresses (heat and nutritional) on growth and reproductive performance of Malpura rams under semi-arid tropical environment. J. Anim. Physiol. Anim. Nutr. 2016, 100, 938-946. [CrossRef]

16. Quinteiro-Filho, W.M.; Rodrigues, M.; Ribeiro, A.; Ferraz-de-Paula, V.; Pinheiro, M.; Sá, L.R.M.d.; Ferreira, A.J.P.; Palermo-Neto, J. Acute heat stress impairs performance parameters and induces mild intestinal enteritis in broiler chickens: Role of acute hypothalamic-pituitary-adrenal axis activation. J. Anim. Sci. 2012, 90, 1986-1994. [CrossRef] [PubMed]

17. Akhavan-Salamat, H.; Ghasemi, H.A. Alleviation of chronic heat stress in broilers by dietary supplementation of betaine and turmeric rhizome powder: Dynamics of performance, leukocyte profile, humoral immunity, and antioxidant status. Trop. Anim. Health Prod. 2016, 48, 181-188. [CrossRef]

18. He, S.; Zhao, S.; Dai, S.; Liu, D.; Bokhari, S.G. Effects of dietary betaine on growth performance, fat deposition and serum lipids in broilers subjected to chronic heat stress. J. Anim. Sci. 2015, 86, 897-903. [CrossRef]

19. Hosseini-Vashan, S.; Golian, A.; Yaghobfar, A. Growth, immune, antioxidant, and bone responses of heat stress-exposed broilers fed diets supplemented with tomato pomace. Int. J. Biometeorol. 2016, 60, 1183-1192. [CrossRef]

20. Wan, X.; Zhang, J.; He, J.; Bai, K.; Zhang, L.; Wang, T. Dietary enzymatically treated Artemisia annua L. supplementation alleviates liver oxidative injury of broilers reared under high ambient temperature. Int. J. Biometeorol. 2017, 61, 1629-1636. [CrossRef]

21. Agrawal, D.K.; Mishra, P.K. Curcumin and its analogues: Potential anticancer agents. Med. Res. Rev. 2010, 30, 818-860. [PubMed]

22. Jin, W.; Wang, J.; Zhu, T.; Yuan, B.; Ni, H.; Jiang, J.; Wang, H.; Liang, W. Anti-inflammatory effects of curcumin in experimental spinal cord injury in rats. Inflamm. Res. 2014, 63, 381-387. [CrossRef] [PubMed]

23. Mosley, C.A.; Liotta, D.C.; Snyder, J.P. Highly active anticancer curcumin analogues. In The Molecular Targets and Therapeutic Uses of Curcumin in Health and Disease; Springer: Berlin, Germany, 2007; pp. 77-103.

24. Wongcharoen, W.; Phrommintikul, A. The protective role of curcumin in cardiovascular diseases. Int. J. Cardiol. 2009, 133, 145-151. [CrossRef] [PubMed]

25. Jaguezeski, A.M.; Perin, G.; Crecencio, R.B.; Baldissera, M.D.; Stefanil, L.M.; da Silva, A.S. Addition of Curcumin in Dairy Sheep Diet in the Control of Subclinical Mastitis. Acta Sci. Vet. 2018, 46, 7. [CrossRef]

26. Bulku, E.; Stohs, S.J.; Cicero, L.; Brooks, T.; Halley, H.; Ray, S.D. Curcumin exposure modulates multiple pro-apoptotic and anti-apoptotic signaling pathways to antagonize acetaminophen-induced toxicity. Curr. Neurovasc. Res. 2012, 9, 58-71. [CrossRef] [PubMed]

27. Ahmadi, F. Effect of turmeric (Curcumin longa) powder on performance, oxidative stress state and some of blood parameters in broiler fed on diets containing aflatoxin B1. Glob. Vet. 2010, 5, 312-317.

28. Emadi, M.; Kermanshahi, H. Effect of turmeric rhizome powder on the activity of some blood enzymes in broiler chickens. Int. J. Poult. Sci. 2007, 6, 48-51.

29. Riasi, A.; Kermanshahi, H.; Fathi, M. Effect of Turmeric rhizome powder (Curcuma longa) on performance, egg quality and some blood serum parameters of laying hens. In Proceedings of the 1st Mediterranean Summit of World Poultry Science Association, Chalkidiki, Greece, 7-10 May 2008.

30. Molosse, V.; Souza, C.F.; Baldissera, M.D.; Glombowsky, P.; Campigotto, G.; Cazaratto, C.J.; Stefani, L.M.; da Silva, A.S. Diet supplemented with curcumin for nursing lambs improves animal growth, energetic metabolism, and performance of the antioxidant and immune systems. Small Rumin. Res. 2019, 170, 74-81. [CrossRef]

31. Geng, R.-Q.; Chang, H.; Yang, Z.-P.; Sun, W.; Wang, L.-P.; Lu, S.-X.; Tsunoda, K.; Ren, Z. Study on origin and phylogeny status of Hu sheep. Asian-Australas. J. Anim. Sci. 2003, 16, 743-747. [CrossRef]

32. DiGiacomo, K.; Simpson, S.; Leury, B.; Dunshea, F. Dietary betaine impacts the physiological responses to moderate heat conditions in a dose dependent manner in sheep. Animals 2016, 6, 51. [CrossRef]

33. Liu, H.; Li, K.; Mingbin, L.; Zhao, J.; Xiong, B. Effects of chestnut tannins on the meat quality, welfare, and antioxidant status of heat-stressed lambs. Meat Sci. 2016, 116, 236-242. [CrossRef] [PubMed]

34. Alhidary, I.; Shini, S.; Al Jassim, R.; Gaughan, J. Physiological responses of Australian Merino wethers exposed to high heat load. J. Anim. Sci. 2012, 90, 212-220. [CrossRef] [PubMed] 
35. Xie, Z.; Shen, G.; Wang, Y.; Wu, C. Curcumin supplementation regulates lipid metabolism in broiler chickens. Poult. Sci. 2018, 98, 422-429. [CrossRef] [PubMed]

36. Shin, S.K.; Ha, T.Y.; McGregor, R.A.; Choi, M.S. Long-term curcumin administration protects against atherosclerosis via hepatic regulation of lipoprotein cholesterol metabolism. Mol. Nutr. Food Res. 2011, 55, 1829-1840. [CrossRef] [PubMed]

37. Zingg, J.M.; Hasan, S.T.; Meydani, M. Molecular mechanisms of hypolipidemic effects of curcumin. Biofactors 2013, 39, 101-121. [CrossRef] [PubMed]

38. Hajati, H.; Hassanabadi, A.; Golian, A.; Nassiri-Moghaddam, H.; Nassiri, M.R. The effect of grape seed extract and vitamin $\mathrm{C}$ feed supplementation on some blood parameters and HSP70 gene expression of broiler chickens suffering from chronic heat stress. Ital. J. Anim. Sci. 2015, 14, 3273. [CrossRef]

39. Jaguezeski, A.M.; Gündel, S.S.; Favarin, F.R.; Gündel, A.; Souza, C.F.; Baldissera, M.D.; Cazarotto, C.C.; Volpato, A.; Fortuoso, B.F.; Ourique, A.F. Low-dose curcumin-loaded Eudragit L-100-nanocapsules in the diet of dairy sheep increases antioxidant levels and reduces lipid peroxidation in milk. J. Food Eng. 2019, e12942. [CrossRef]

40. Lin, H.; Decuypere, E.; Buyse, J. Acute heat stress induces oxidative stress in broiler chickens. Comp. Biochem. Physiol. A Mol. Integr. Physiol. 2006, 144, 11-17. [CrossRef] [PubMed]

41. Bauché, F.; Fouchard, M.-H.; Jégou, B. Antioxidant system in rat testicular cells. FEBS Lett. 1994, 349, $392-396$. [CrossRef]

42. Li, Y.; Cao, Y.; Wang, F.; Li, C. Scrotal heat induced the Nrf2-driven antioxidant response during oxidative stress and apoptosis in the mouse testis. Acta. Histochem. 2014, 116, 883-890. [CrossRef]

43. Zhang, J.; Bai, K.; Su, W.; Wang, A.; Zhang, L.; Huang, K.; Wang, T. Curcumin attenuates heat-stress-induced oxidant damage by simultaneous activation of GSH-related antioxidant enzymes and Nrf2-mediated phase II detoxifying enzyme systems in broiler chickens. Poult. Sci. 2018, 97, 1209-1219. [CrossRef] [PubMed]

44. Jaguezeski, A.M.; Perin, G.; Bottari, N.B.; Wagner, R.; Fagundes, M.B.; Schetinger, M.R.C.; Morsch, V.M.; Stein, C.S.; Moresco, R.N.; Barreta, D.A. Addition of curcumin to the diet of dairy sheep improves health, performance and milk quality. Anim. Feed Sci. Tech. 2018, 246, 144-157. [CrossRef]

45. Cao, D.; Li, H.; Yi, J.; Zhang, J.; Che, H.; Cao, J.; Yang, L.; Zhu, C.; Jiang, W. Antioxidant properties of the mung bean flavonoids on alleviating heat stress. PLoS ONE 2011, 6, e21071. [CrossRef] [PubMed]

46. Liu, L.; He, J.; Xie, H.; Yang, Y.; Li, J.; Zou, Y. Resveratrol induces antioxidant and heat shock protein mRNA expression in response to heat stress in black-boned chickens. Poult. Sci 2013, 93, 54-62. [CrossRef] [PubMed]

47. Aggarwal, A.; Upadhyay, R. Heat stress and immune function. In Heat Stress and Animal Productivity; Springer: Berlin, Germany, 2013; pp. 113-136.

48. Min, L.; Zheng, N.; Zhao, S.; Cheng, J.; Yang, Y.; Zhang, Y.; Yang, H.; Wang, J. Long-term heat stress induces the inflammatory response in dairy cows revealed by plasma proteome analysis. Biochem. Biophys. Res. Commun. 2016, 471, 296-302. [CrossRef] [PubMed]

49. Deng, W.; Dong, X.; Tong, J.; Zhang, Q. The probiotic Bacillus licheniformis ameliorates heat stress-induced impairment of egg production, gut morphology, and intestinal mucosal immunity in laying hens. Poult. Sci. 2012, 91, 575-582. [CrossRef] [PubMed]

50. Smith, M. Effects of different levels of zinc on the performance and immunocompetence of broilers under heat stress. Poult. Sci. 2003, 82, 1580-1588.

51. Liu, D.Y.; He, S.J.; Liu, S.Q.; Tang, Y.G.; Jin, E.H.; Chen, H.L.; Li, S.H.; Zhong, L.T. Daidzein enhances immune function in late lactation cows under heat stress. Anim. Sci. J. 2014, 85, 85-89. [CrossRef] [PubMed]

52. Çiftçi, O. Curcumin prevents toxic effects of 2, 3, 7, 8-tetrachlorodibenzo-p-dioxin (TCDD) on humoral immunity in rats. Food Agr. Immunol. 2011, 22, 31-38. [CrossRef]

53. Krishnaraju, A.; Sundararaju, D.; Sengupta, K.; Venkateswarlu, S.; Trimurtulu, G. Safety and toxicological evaluation of demethylatedcurcuminoids; a novel standardized curcumin product. Toxicol. Mech. Methods 2009, 19, 447-460. [CrossRef]

54. Dandekar, P.; Dhumal, R.; Jain, R.; Tiwari, D.; Vanage, G.; Patravale, V. Toxicological evaluation of pH-sensitive nanoparticles of curcumin: Acute, sub-acute and genotoxicity studies. Food Chem. Toxicol. 2010, 48, 2073-2089. [CrossRef] [PubMed]

55. Lin, C.; Shin, D.-G.; Park, S.G.; Chu, S.B.; Gwon, L.W.; Lee, J.-G.; Yon, J.-M.; Baek, I.-J.; Nam, S.-Y. Curcumin dose-dependently improves spermatogenic disorders induced by scrotal heat stress in mice. Food Funct. 2015, 6, 3770-3777. 
56. Juan, M.E.; Gonzalez-Pons, E.; Munuera, T.; Ballester, J.; Rodriguez-Gil, J.E.; Planas, J.M. trans-Resveratrol, a natural antioxidant from grapes, increases sperm output in healthy rats. J. Nutr. 2005, 135, 757-760. [CrossRef] [PubMed]

57. Hong, Z.; Hailing, L.; Hui, M.; Guijie, Z. Effect of vitamin E supplementation on development of reproductive organs in Boer goat. Anim. Reprod. Sci. 2009, 113, 93-101. [CrossRef] [PubMed]

58. Aktas, C.; Kanter, M. A morphological study on Leydig cells of scrotal hyperthermia applied rats in short-term. J. Mol. Histol. 2009, 40, 31-39. [CrossRef] [PubMed]

59. Stocco, D.M.; Wang, X.; Jo, Y.; Manna, P.R. Multiple signaling pathways regulating steroidogenesis and steroidogenic acute regulatory protein expression: more complicated than we thought. Mol. Endocrinol. 2005, 19, 2647-2659. [CrossRef] [PubMed]

60. Rizk, S.M.; Zaki, H.F.; Mina, M.A. Propolis attenuates doxorubicin-induced testicular toxicity in rats. Food. Chem. Toxicol. 2014, 67, 176-186. [CrossRef]

61. Bozkaya, F.; Atli, M.; Guzeloglu, A.; Kayis, S.; Yildirim, M.; Kurar, E.; Yilmaz, R.; Aydilek, N. Effects of long-term heat stress and dietary restriction on the expression of genes of steroidogenic pathway and small heat-shock proteins in rat testicular tissue. Andrologia 2017, 49, e12668. [CrossRef] [PubMed]

62. Lin, C.; Choi, Y.S.; Park, S.G.; Gwon, L.W.; Lee, J.G.; Yon, J.-M.; Baek, I.-J.; Lee, B.J.; Yun, Y.W.; Nam, S.-Y. Enhanced protective effects of combined treatment with $\beta$-carotene and curcumin against hyperthermic spermatogenic disorders in mice. Biomed. Res. Int. 2016, 2016. [CrossRef] [PubMed]

63. Cormier, M.; Ghouili, F.; Roumaud, P.; Bauer, W.; Touaibia, M.; Martin, L.J. Influences of flavones on cell viability and cAMP-dependent steroidogenic gene regulation in MA-10 Leydig cells. Cell Biol. Toxicol. 2018, 34, 23-38. [CrossRef] [PubMed]

64. Cormier, M.; Ghouili, F.; Roumaud, P.; Martin, L.J.; Touaibia, M. Influence of flavonols and quercetin derivative compounds on MA-10 Leydig cells steroidogenic genes expressions. Toxicol. in Vitro 2017, 44, 111-121. [CrossRef] [PubMed]

65. Kanter, M.; Aktas, C.; Erboga, M. Heat stress decreases testicular germ cell proliferation and increases apoptosis in short term: an immunohistochemical and ultrastructural study. Toxicol. Ind. Health. 2013, 29, 99-113. [CrossRef] [PubMed]

66. Paul, C.; Teng, S.; Saunders, P.T. A single, mild, transient scrotal heat stress causes hypoxia and oxidative stress in mouse testes, which induces germ cell death. Biol. Reprod. 2009, 80, 913-919. [CrossRef] [PubMed]

67. Fan, X.; Xi, H.; Zhang, Z.; Liang, Y.; Li, Q.; He, J. Germ cell apoptosis and expression of Bcl-2 and Bax in porcine testis under normal and heat stress conditions. Acta Histochem. 2017, 119, 198-204. [CrossRef]

68. Tan, Q.; An, C.; Xiao, Y.; Liao, Z. Protective effect of lycium barbarum polysaccharides against heat stress-induced germ cell apoptosis in rats and its mechanism. Zhonghua Nan Ke Xue Natl. J. Androl. 2012, 18, 88-92. [PubMed]

69. Kanter, M.; Aktas, C.; Erboga, M. Curcumin attenuates testicular damage, apoptotic germ cell death, and oxidative stress in streptozotocin-induced diabetic rats. Mol. Nutr. Food Res. 2013, 57, 1578-1585. [CrossRef]

70. Verma, R.J.; Mathuria, N. Effect of curcumin on aflatoxin-induced biochemical changes in testis of mice. Fertil. Steril. 2009, 91, 597-601. [CrossRef]

(C) 2019 by the authors. Licensee MDPI, Basel, Switzerland. This article is an open access article distributed under the terms and conditions of the Creative Commons Attribution (CC BY) license (http://creativecommons.org/licenses/by/4.0/). 